\title{
The feasibility study of a grid connected PV system to meet the power demand in Bangladesh - A case study
}

\author{
Mohammad Shuhrawardy, Kazi Tanvir Ahmmed \\ Department of Applied Physics, Electronics and Communication Engineering, University of Chittagong, Chittagong, Bangladesh \\ Email address: \\ mswardy@cu.ac.bd (M. Shuhrawardy), tanvir@cu.ac.bd (K. T. Ahmmed)
}

To cite this article:

Mohammad Shuhrawardy, Kazi Tanvir Ahmmed. The Feasibility Study of a Grid Connected PV System to Meet the Power Demand in Bangladesh - A Case Study. American Journal of Energy Engineering. Vol. 2, No. 2, 2014, pp. 59-64. doi: 10.11648/j.ajee.20140202.12

\begin{abstract}
This paper represents the feasibility study of a grid connected PV system with battery backup in the south-east part of Bangladesh. In Bangladesh, only 53\% of the total population gets access to grid power and yet, the current consumers cannot be provided with uninterrupted and quality supply of electricity due to the inadequate generation compared to the national demand. The world is gradually moving towards sustainable renewable energy sources due to diminishing fossil fuel energy resources and increasing demand for power. Most of the power stations in Bangladesh are based on fossil fuels. Fossil fuels are not environment friendly and are responsible for global warming. So a renewable grid connected power system with battery backup can be a better option to provide continuous power in a load shedding prone country like Bangladesh and also to reduce the emission of greenhouse gases. Our proposed system is simulated using HOMER optimization tool and the simulation results and analysis of the system are presented in the paper.
\end{abstract}

Keywords: Renewable Energy, Non-renewable Energy, Fossil Fuels, Grid Connected System, Global Warming, Independent Power Producers' (IPPs), Rental Power Producers (RPPs)

\section{Introduction}

Electric power supply is the key for economic development of any country. To sustain the economic development huge amount of electricity is required in all sectors. However in Bangladesh there is a huge gap between the supply and demand of electricity. In United States the energy consumption rate is $11.4 \mathrm{~kW}$ per person where in developing countries, like India, the per person energy use rate is closer to $0.7 \mathrm{~kW}$. Bangladesh has the lowest consumption rate with $0.2 \mathrm{~kW}$ per person [1]. There are many different sources of energy that are naturally available throughout the world in different forms. Depending on regeneration energy can be categorized into two main different sources: renewable and non-renewable energy sources [2]. The sources that can be replenished or which are available in plenty in nature are renewable energy sources [3]. By far they are the cleanest and more environment-friendly sources of energy available on this planet, as they do not cause any natural imbalances. Solar energy, wind energy, biomass energy, tidal force, hydropower and geothermal energy are the major instances of renewable energy sources. The sources that cannot be replaced or can be replaced only very slowly by natural processes are non-renewable energy sources. The fossil fuels- natural gas, oil and coal, are the main examples of non-renewable energy sources.

Today's global energy production is mainly, in fact $80.6 \%$ dependent on fossil fuels [4]. But the fossil fuels are limited and their use is responsible for the global climate change due to the emission of greenhouse gases like carbon dioxide. WHO (World Health Organization) estimates that climate change is already causing more than 150,000 deaths a year [5]. Being concerned about the negative impact of conventional energy sources on environment and to provide clean and sustainable energy, there is an increasing demand of energy from renewable energy sources.

In this paper we focused our research on the feasibility study and cost analysis of a grid connected PV system in Bangladesh. We performed our analysis in University of Chittagong which is situated in the south-east part of Bangladesh. The HOMER (Hybrid Optimization Model for Electric Renewable) optimization tool is used for simulating the proposed system. 


\section{Electricity Scenario of Bangladesh}

Electricity, the most convenient form of energy, is a vital ingredient to upgrade the socio-economic condition and to alleviate poverty [6]. Bangladesh is a densely populated country with 142.3 million people [7]. Only $53 \%$ of the country's population has access to grid electricity with 265 $\mathrm{kWh}$ per capita generations, which is very low compared to other developing countries in the world [8]. But it is not possible to meet the electricity demand for the current consumers due to the insufficient production of electricity around the country. This is because the government is unable to ensure the supply of natural gas, the primary fuel used to produce electricity in Bangladesh. Many power plants are idle due to the shortage of gas supply and this creates a struggling situation of electricity generation. On the other hand, most of the public power stations of the country have become very old and they are operating lower than their rated capacity. So load shedding is a regular matter in the country [6]. At present the maximum generation is $6066 \mathrm{MW}$ against the average demand of $7518 \mathrm{MW}$ with a load shedding of $1452 \mathrm{MW}$ [9].

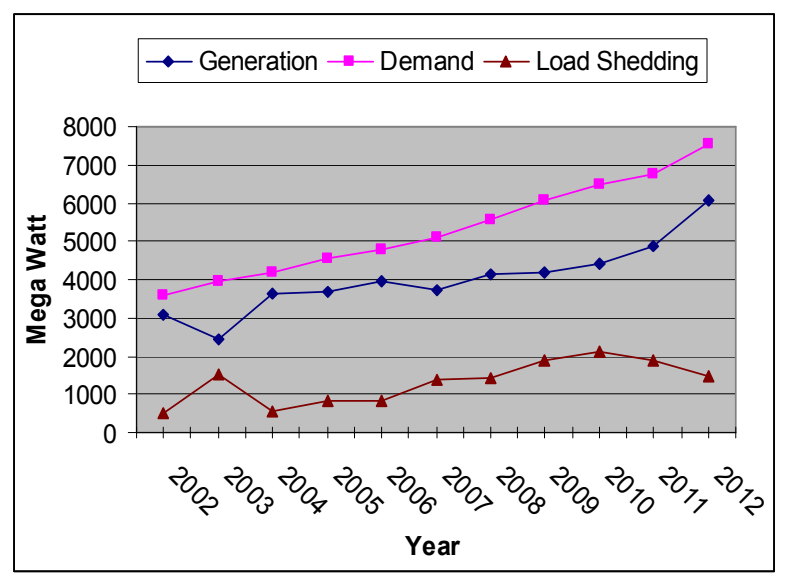

Figure 1. Electricity Demand, Generation and Load Shedding Scenario in Bangladesh from 2002 to 2012 [9], [10], and [11].

Due to the growth in almost all sectors, electricity demand in Bangladesh is increasing day by day. To face the increasing demand and because of time limitations for coal mining, gas supply constrains and lack of other resources, Government has initiated some high-cost temporary solutions, on an emergency basis, such as rental power and small independent power producers' (IPPs), which are mainly diesel or high sulphur fuel oil (HSFO) based. As a result, in just two years (from 2010 to 2012), there was a substantial change in the generation capacity profile. Natural gas share fell from $88 \%$ to $67 \%$ whereas high sulphur content fuel oil rose from $3 \%$ to $22 \%$. The share of diesel, which is more expensive, trebled from $2 \%$ to $6 \%$. The generation profile is now dominated by less efficient reciprocating engines which now represent $39 \%$ of the generation capacity [12]. Under contracts between the Power Development Board (PDB) and the rental power producers (RPPs), the PDB guarantees access to fuel by the
RPPs at lower rates charged by the Bangladesh petroleum corporation (BPC) to other consumers. On the contrary, the PDB sells electricity at prices lower than the prices the PDB spends to purchase from generators. A BIDS (Bangladesh Institute of Development Studies) study estimated that the average cost of un-served energy is $\$ 0.344$ per kilowatt-hour $(\mathrm{kWh})$, while the average bulk tariff on electricity is $\$ 0.052$ per $\mathrm{kWh}(1 \mathrm{USD}=77.76 \mathrm{BDT})$ $[13,14]$.

Bangladesh has a vast potential for renewable energy which can be used to meet the power shortage. Out of various renewable energy sources solar energy can be effectively used in the country. The geographical position of Bangladesh is very favorable for the utilization of solar energy. The amount of annual solar radiation in Bangladesh varies from 1840 to $1575 \mathrm{kWh} / \mathrm{m}^{2}$, which is $50-100 \%$ higher than in Europe $[15,16]$. Taking an annual average solar radiation of $1800 \mathrm{kWh} / \mathrm{m}^{2}$, only $0.00083 \%$ of the incident radiation will be enough to meet the present electricity demand of the country.

\section{A Grid Connected PV System with Battery Backup}

A grid connected power system is a power system that involves getting power from solar energy and/or other renewable energy sources, such as wind and hydro, and using the grid as backup. But in countries, like Bangladesh, where load shedding is a common this type of power system fails to provide continuous electricity to the users when there is no energy coming from the sun or other renewable energy sources and a blackout from grid occurs. Hence we proposed a grid connected PV system with battery backup, which is able to provide uninterrupted power supply at any condition. A grid connected system with battery backup is mainly composed of solar panels, a battery bank, a charge controller, an inverter/charger (converter), a utility grid and a two way electric meter (Net meter). The overall components of the system are shown in figure 2 .

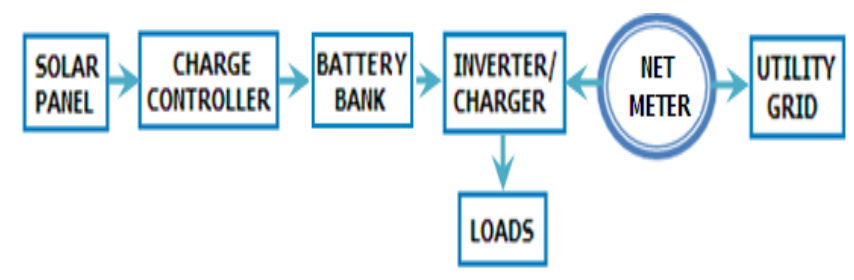

Figure 2. Grid connected PV system with battery backup.

\section{Load Profile of the Proposed Area}

Our work provides a design of a grid connected PV system with battery backup for the IT building of University of Chittagong. The building consists of two departments and an ICT centre. An estimation of the electrical appliances used by the building is given in the 
table below. The over all loads of the building is about $80 \mathrm{~kW}$. But all loads do not work at a time, while each load working at a particular time.

Table 1. Typical electrical appliances used by the IT building of University of Chittagong

\begin{tabular}{lcc}
\hline Appliance item & $\begin{array}{c}\text { Typical Power } \\
\text { Rating (W) }\end{array}$ & Quantity \\
\hline Ceiling fan & 80 & 160 \\
Tube light & 40 & 200 \\
Bulb & 60 & 40 \\
Computer & 400 & 120 \\
Refrigerator & 110 & 3 \\
Air conditioner & 1800 & 4 \\
Water pump & 746 & 1 \\
Laser printer & 436 & 6 \\
Other loads & 3000 & - \\
\hline
\end{tabular}

The office starts at 8.00 am and the class at 9.00 am and both closes at $5.00 \mathrm{pm}$. Normally, load demand is high at afternoon in the area under investigation. The load demands after the sunset is very low, only the refrigerators and few lights serve the load. In winter load requirement is small and in summer it is high. The load demand is high in the month of May and low in June because of rain vacation thorough out the whole month. Figure 3 shows the hourly load profile for a day in the month of May for the proposed area. The average daily load profile for the whole year is shown in figure 4 . On an average the daily load demand is $304 \mathrm{kWh} /$ day and the peak demand is $69 \mathrm{~kW}$.

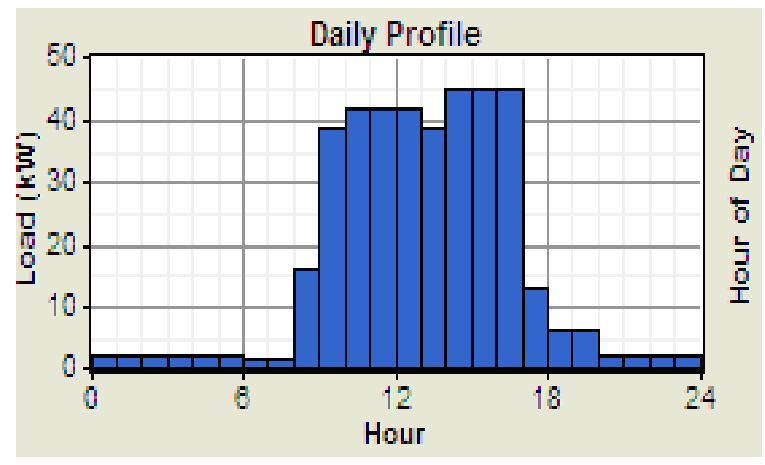

Figure 3. Hourly load profile for a day in the month of May for the proposed area.

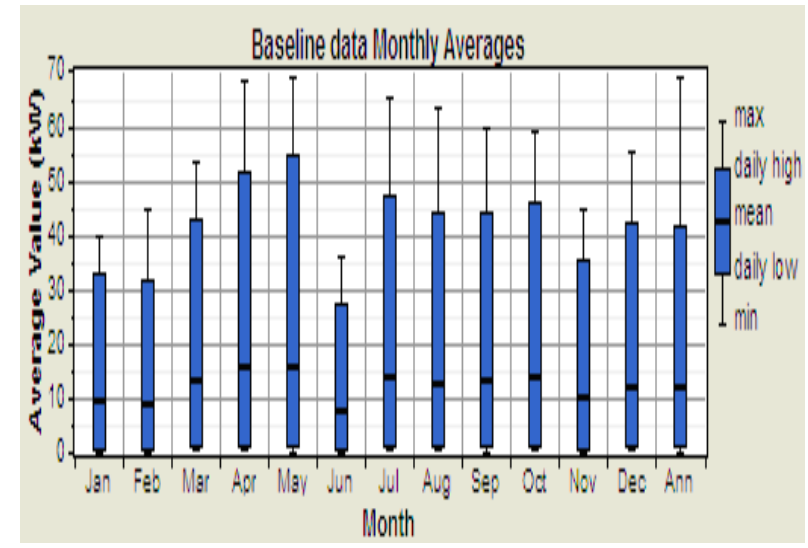

Figure 4. Monthly average load data for the proposed area.

\section{Solar Radiation}

The latitude and longitude of the site under investigation are $22^{\circ} 21^{\prime} \mathrm{N}$ and $95^{\circ} 50^{\prime} \mathrm{E}$, respectively. HOMER uses these data to introduce the average daily radiation and clearness index for twelve months (Figure 5). The annual average solar radiation is $5.054 \mathrm{kWh} / \mathrm{m}^{2} / \mathrm{d}$. The maximum daily radiation is in the month of May, which is best suitable for our site as the load demand is also high is this month. The clearness index is the highest in the month of January and the lowest in the month of July.

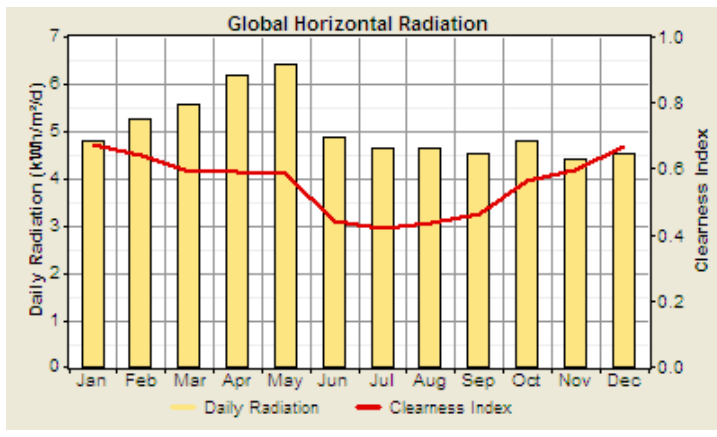

Figure 5. Average daily solar radiation and clearness index.

\section{Implementation of the HOMER Model}

\subsection{System Configuration and Components}

The HOMER schematic of the proposed system is given in the figure 6. The components considered are PV system, converter, battery, grid and loading system. Table 2 shows the component wise cost of the system and all cost are estimated considering the market price of Bangladesh.

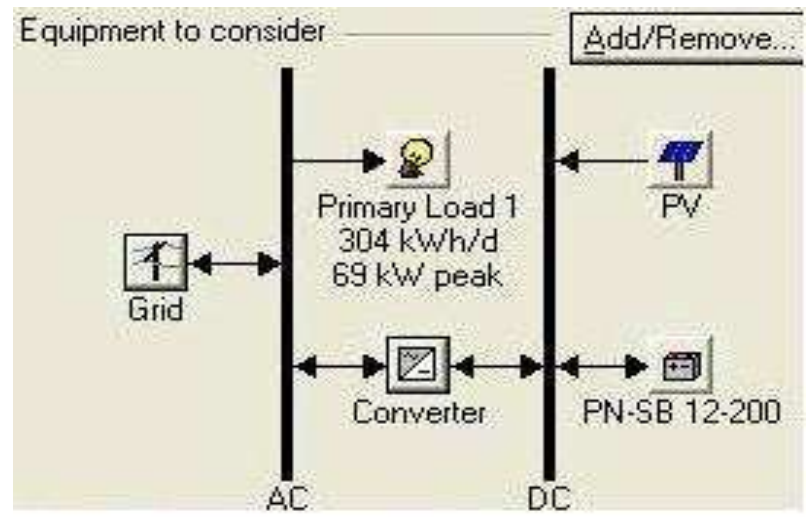

Figure 6. The HOMER schematic of the proposed system.

Table 2. Cost of different components of the proposed system.

\begin{tabular}{lccc}
\hline Component & $\begin{array}{c}\text { Capital } \\
\text { cost }(\$)\end{array}$ & $\begin{array}{c}\text { Replacement } \\
\text { cost }(\mathbf{\$})\end{array}$ & $\begin{array}{c}\text { O \& M cost } \\
(\mathbf{\$} / \mathbf{y r})\end{array}$ \\
\hline PV system (1kW) & 3500 & 2800 & 0 \\
Converter (1kW) & 850 & 730 & 0 \\
Battery(12V, 200 Ah) & 800 & 680 & 0 \\
\hline
\end{tabular}




\subsubsection{PV System}

For the system the PV panels considered are the crystalline solar panels as they have high efficiency, about $21.5 \%$ [17], and long lifetime. At present the production cost of the best crystalline-silicon (c-Si) PV module in China is $\$ 0.5 / \mathrm{W}$ and will fall to $\$ 0.36 / \mathrm{W}$ by the end of 2017 [18]. The capital and replacement costs for $1 \mathrm{~kW}$ PV system are considered to be $\$ 3500$ and $\$ 2800$ respectively. The capital cost includes PV modules, structural components, the cost of installation and the charge controller cost, as HOMER does not model the battery charge controller as a separate component. An efficiency of $90 \%$ for solar panel and an efficiency of $95 \%$ for charge controller are considered. So the derating factor is $85.5 \%$. No maintenance cost was considered for the PV system because crystalline solar panels require little or no maintenance. The lifetime of the PV panels are taken as 25 years and no tracking is considered in the PV system. Such a size of PV panel for the system is considered so that it can provide at least $50 \%$ of the total load demand.

\subsubsection{Converter (Inverter/Charger)}

Converter is one of the key components of a PV system. It is also called an inverter/charger. It is an electrical component that can works both as an inverter (DC to AC) and rectifier (AC to DC) depending on the direction of flow of power. It can also operate simultaneously with an ac generator. For the system a grid connected true sine wave power inverter/charger is considered as it produces the closest to a pure sine wave of all power inverters and in many cases produces cleaner power than the utility company itself [19]. The capital cost of inverter is $\$ 850 / \mathrm{kW}$ and replacement cost is $\$ 730 / \mathrm{kW}$. It has no operational and maintenance cost. The inverter's efficiency is $95 \%$ and lifetime is 15 years, which means that it has to be replaced once in 25 years period of system lifetime.

\subsubsection{Battery}

The battery provides backup power during power outage on the grid in a cloudy day or at night. Today different types and classifications of batteries, each with specific design and performance characteristics suited for particular applications, are manufactured. In this paper deep cycle AGM battery is considered, as they are maintenance free and have superior performance and longer lifetime, where most people use flooded solar battery. Because they are completely sealed, unlike flooded battery, they can't be spilled, do not need periodic watering, and emit no corrosive fumes, the electrolyte will not stratify and no equalization charging is required [20], [21]. The battery considered is Phaesun PN-SB 12-200 with nominal voltage of $12 \mathrm{~V}$ and capacity of 200Ah $(2.24 \mathrm{kWh})$. The capital and replacement cost of each battery are $\$ 800$ and $\$ 680$, respectively. The number of batteries considered is to give at least 3 hour backup continuously.

\subsubsection{Grid Input}

In Bangladesh the average selling price of grid power is lower than the average generation cost, selling price is about $60 \%$ of the average generation cost [22]. At present the proposed area uses the category " $\mathrm{F}$ " tariff offered by the grid, which has two rates $-\$ 0.077 / \mathrm{kWh}$ for off peak period and $\$ 0.120 / \mathrm{kWh}$ for peak period. We considered the same prices as sellback prices for off peak period and peak period respectively. The demand rate is $\$ 0.579 / \mathrm{kWh} / \mathrm{month}$. We considered monthly net metering scheme in the simulation. Net metering is a billing system by which the utility allows one to sell power to the grid at the retail rate [23]. At the end of the billing period one will be charged for the net amount purchased (total purchases minus sales).

\subsection{Economics and Constraints Analysis}

The project lifetime is considered to be 25 years and the annual interest rate is taken as $6 \%$. No fixed operation and maintenance costs are considered as they are given in the individual components. Operating reserve as percentage of the current load is $10 \%$ and this reserve as a percentage of solar power output is $20 \%$. Annual capacity shortage is set to zero.

\section{Optimized Simulation Result}

After simulation HOMER omits all infeasible system configurations and shows a list for the feasible combinations sorted by net present cost (NPC). The simulation results data for our proposed system obtained from HOMER is shown in figure 7.

\begin{tabular}{|c|c|c|c|c|c|c|c|c|c|}
\hline 140 & $\begin{array}{l}\mathrm{FV} \\
(\mathrm{kW})\end{array}$ & PN.SB 1... & $\begin{array}{l}\text { Conv. } \\
(k \mathrm{~W})\end{array}$ & $\begin{array}{l}\text { Grid } \\
(\mathrm{kW})\end{array}$ & $\begin{array}{l}\text { Initial } \\
\text { Capital }\end{array}$ & $\begin{array}{l}\text { Operating } \\
\text { Cost }(\$ / y r)\end{array}$ & $\begin{array}{l}\text { Total } \\
\text { NPC }\end{array}$ & $\left|\begin{array}{c}C O E \\
(\$ / k W h)\end{array}\right|$ & $\begin{array}{l}\text { Ren. } \\
\text { Frac. }\end{array}$ \\
\hline & & & & 400 & $\$ 0$ & 9,363 & $\$ 119,687$ & 0.084 & 0.00 \\
\hline 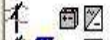 & & 40 & 40 & 400 & $\$ 66,000$ & 11,742 & $\$ 216,104$ & 0.152 & 0.00 \\
\hline & 45 & & 40 & 400 & $\$ 191,500$ & 5,095 & $\$ 256,636$ & 0.166 & 0.53 \\
\hline 㑭国 & 45 & $40^{\circ}$ & 40 & 400 & $\$ 223500$ & 6,699 & $\$ 309136$ & 0.200 & 0.53 \\
\hline
\end{tabular}

Figure 7. Optimized simulation results from HOMER.

Our proposed optimized result contains PV panel of 45 $\mathrm{kW}$, converter of $40 \mathrm{~kW}$ and 40 batteries for storage. The power demand supplied by the PV system is $56 \%$ and the other $44 \%$ is purchased from the grid (Figure 8 ). There is no unmet electric load and capacity shortage is zero. Excess electricity fraction is almost zero percent. The amount of PV energy that is used to serve the load is $92 \%$ and the other $8 \% \mathrm{PV}$ energy is sold to the grid around the year. The renewable fraction is 0.535 and the maximum renewable penetration is $113 \%$.

\begin{tabular}{|c|c|c|c|c|c|}
\hline Production & $\mathrm{kWh} / \mathrm{yr}$ & $\%$ & Quantity & $\mathrm{kWh} / \mathrm{gr}$ & $\%$ \\
\hline PV array & 71,894 & 56 & Excess electricity & 0.920 & 0.00 \\
\hline Grid purchases & 56,256 & 44 & Unmet electric load & 0.00 & 0.00 \\
\hline Total & 128,150 & 100 & Capacity shortage & 0.00 & 0.00 \\
\hline Consumption & kWh/yr & $\%$ & Quantity & & \\
\hline AC primary load & 110,960 & 92 & Renewable fraction & & 0.535 \\
\hline Grid sales & 9,999 & 8 & Max. renew. penetrat & & $113 \%$ \\
\hline Total & 120,959 & 100 & & & \\
\hline
\end{tabular}

Figure 8. Electrical Outputs of simulation result. 
The monthly average electric power produced by PV system and grid is shown in the figure 9. The PV production is high in the months of January and February because of higher clearness index and low in the months of July and August for lower clearness index.

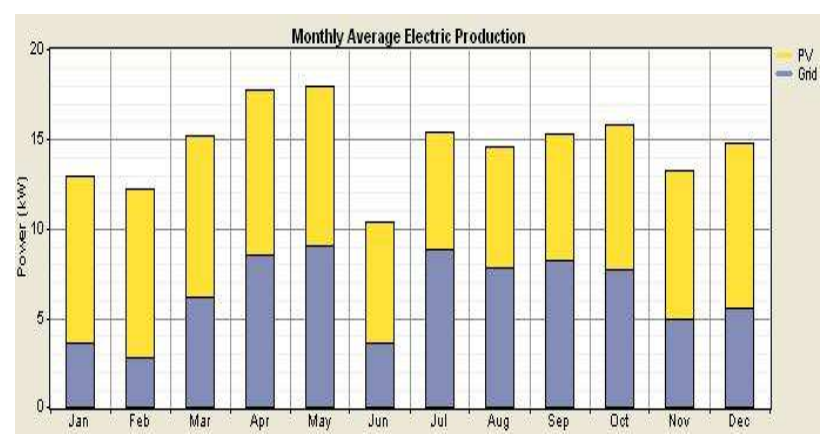

Figure 9. Monthly average electric production from PV and grid.

The cash flow summary is given in figure 10. The highest part of the cost is due to the PV panels, although there is no replacement and operating cost in this purpose. All cost associated with grid is considered as operating cost. The total net present cost (NPC) is $\$ 309,136$, the capital cost is $\$ 223,500$, the operating cost is $\$ 6699 / \mathrm{yr}$ and the cost of energy is $\$ 0.200 / \mathrm{kWh}$.

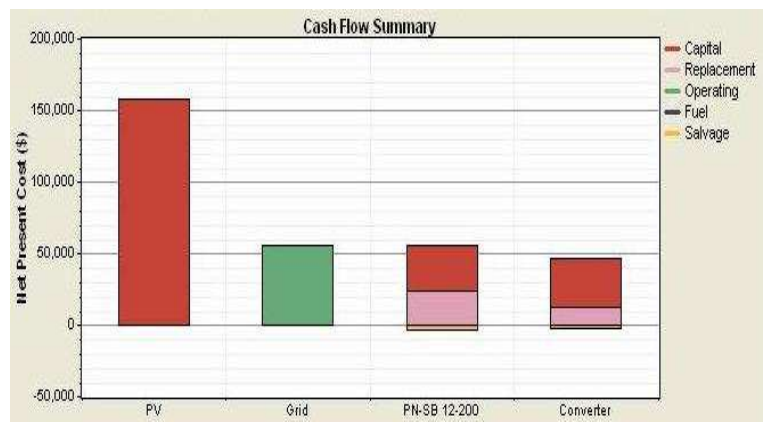

Figure 10. Cost summary of the proposed system.

\section{Analysis of the Simulation Result}

From simulation result (Figure 7), first optimum option is using the grid with government subsidy. The second option is to use grid with battery backup and the third option is using solar plus grid with no battery backup. The fourth option is our proposed option that provides almost continuous power using solar renewable energy plus grid with battery backup. Although the second option can provide continuous power, it will contribute to the overall increase in the load shedding scenario of the country and hence can not be the permanent solution. The first and third options do not provide continuous power. But uninterrupted power supply is must required for all the educational institutions. Completing all the regular activities, performing laboratory experiments, doing research work will be greatly hampered without continuous power. So our proposed system is the ultimate solution to provide uninterrupted power in a load shedding prone country like Bangladesh.

\section{Conclusion}

The power sector of Bangladesh is mainly dependent on natural gas. But the gas supply is decreasing day by day as no new reserve could be discovered and hence the country is suffering a severe power crisis. To minimize the power shortage Government has taken short term plan, on an emergency basis. Under this plan, rental and quick rental power plants are installed using diesel and high sulphur fuel oil (HSFO). The average cost of un-served energy from quick rental power plants is $\$ 0.344 / \mathrm{kWh}$. The cost of energy for our proposed system is $\$ 0.200 / \mathrm{kWh}$ and it will be feasible to install our proposed system in Bangladesh. So our government should increase power generation from renewable sources instead of other conventional sources. If we can generate significant amount of power from renewable energy sources then it will not be necessary to hike the price of electricity so frequently and in this process emission of significant amount of $\mathrm{CO}_{2}$ and other green house gases can be reduced.

\section{References}

[1] A. Zaman, M. A. Rahman and S. Islam, "Design of a hybrid power system for rural area", Journal Basic Science and Technology, 1(2), 1-4, 2012.

[2] http://renewablegreen.net/? $\mathrm{p}=124$ [Accessed on $5^{\text {th }}$ March, 2013]

[3] http://readanddigest.com/what-are-the-different-types-ofenergy-sources/ [Accessed on $19^{\text {th }}$ May, 2013]

[4] Renewable energy policy network for the $21^{\text {st }}$ century (REN21). Renewables 2012, Global Status Report.

[5] World Wide Fund for Nature (WWF). The Energy Report 2011, 100\% Renewable Energy by 2050 .

[6] Unnayan Onneshan Research Report. Electricity Scenario in Bangladesh, November 2011.

[7] Population \& Housing Census 2011, Preliminary Results, July 2011, Bangladesh Bureau of Statistics, Statistics Division, Ministry Of Planning, Government of the People's Republic of Bangladesh.

[8] M. R. Hamid,"Photovoltaic based solar home systemscurrent state of dissemination in rural areas of Bangladesh and future prospect", International Journal of Advanced Research in Electrical, Electronics and Instrumentation Engineering, Vol. 2, Issue 2, February 2013.

[9] Annual Report 2011-2012, Bangladesh Power Development Board.

[10] "Power and Energy Sector Road Map: An Update", June 2011, Finance Division, Ministry of Finance, Government of the People's Republic of Bangladesh.

[11] Annual Report 2007-2008, 2008-2009, 2010-2011, Bangladesh Power Development Board.

[12] Oxford Institute for Energy Studies. "Natural gas in Pakistan and Bangladesh: Current issues and trends", June 2013. 
[13] http://www.dhakatribune.com/economy/2013/jun/18/rentalpower-slows-base-load-power-stations-bids [Accessed on 10 th July, 2013]

[14] http://www.thedailystar.net/beta2/news/quick-rental-powerhelps-fuel-gdp-growth-study/ [ Accessed on $7^{\text {th }}$ July, 2013 ]

[15] M. A. Khan, M. Shamsuddoha, A. A. Helal and A. Hassan, "Climate change mitigation approaches in Bangladesh", Journal of Sustainable Development, vol. 6, no. 7, 2013.

[16] M. R. Islam, and T. H. M. S. Rashid, "Prospects and potential analysis of solar and biomass energy at Pabna district, Bangladesh: A realistic way to mitigate district energy demand", International Journal of Engineering and Advanced Technology (IJEAT), Volume-2, Issue-2, December 2012.

[17] http://energyinformative.org/best-solar-panelmonocrystalline-polycrystalline-thin-film/ [Accessed on 10 th July, 2013]

[18] http://www.greentechmedia.com/articles/read/solar-pvmodule-costs-to-fall-to-36-cents-per-watt [ Accessed on 10 th July, 2013 ]
[19] http://www.freesunpower.com/inverters.php [ Accessed on $12^{\text {th }}$ February, 2013 ]

[20] http://www.bdchargers.com/batterytypes.php [ Accessed on $15^{\text {th }}$ February, 2013]

[21] http://www.altestore.com/store/Deep-CycleBatteries/Batteries-Sealed-Agm/c436/ [ Accessed on 2 nd April, 2013 ]

[22] Power Division Annual Report, 2010-2011(In Bengali), Ministry Of Power, Energy and Mineral Resources, Bangladesh.

[23] S. Talebhagh and H. K. Kareghar, "Applying grid-connected PV systems as supplement to public electricity network in rural area of Iran", International Journal Of Advanced Renewable Energy Research, Vol. 1, Issue. 7, pp. 419- 428, 2012. 